\title{
The story of a tragedy: how people in Haut-Katanga interpret the post-colonial history of Congo*
}

\author{
Benjamin Rubbers \\ Laboratoire d'Anthropologie Sociale et Culturelle, Université de Liège, \\ 7 boulevard du rectorat, 4000 Liège, and Laboratoire d'Anthropologie des \\ Mondes Contemporains, Université Libre de Bruxelles, 44 avenue Jeanne, \\ I05o Bruxelles, Belgium
}

Email: brubbers@ulg.ac.be

\section{A B S T R A C T}

In order to give an account of the Congolese tragedy since independence, the inhabitants of Haut-Katanga often resort to four different narratives: the abandonment by Belgium; the biblical curse on Africans; the conspiracy of Western capitalism; or the alienation of life powers by Whites. Though these four stories offer different scenarios, they are all constructed with two types of actors - Whites and Congolese people. This article suggests that this racial/national frame finds its origins in colonial and national ideologies, which have left their mark on HautKatanga, and that it continues today to structure the narratives through which people remember their post-colonial history. Collective memory and racial/ national identity are reciprocally constituted in these stories, but in different terms. They offer, accordingly, different ways of influencing the present.

\section{N T R O D U G T I O N}

During research on European entrepreneurs in Haut-Katanga (Democratic Republic of Congo), I developed a strong interest in the ways in which Congolese people in this region see White people (Rubbers

* This article was written at the University of Oxford while I was a recipient of a postdoctoral fellowship from the Fondation Wiener-Anspach. Fieldwork in Haut-Katanga was carried out thanks to a research fellowship from the Fonds National de la Recherche Scientifique and the Fondation Bernheim, Belgium. The ideas contained in this article benefited from discussions during two seminars in 2006 at the University of Lubumbashi. Participants illustrated my analysis with new anecdotes, and pushed me to clarify some crucial points about the history and the social distribution of the four narratives. I am also grateful to David Pratten, Pierre Petit and Joël Noret for their critical reading of early drafts. Lastly, I would like to thank Christopher Clapham and the anonymous reviewers for the Journal of Modern African Studies. The final version owes much to their insightful comments. All are of course exonerated from any association with the views expressed in this article. 
2006a). ${ }^{1}$ Unexpectedly, my questions about their perception of Whites inspired long comments about the history of Congo on the part of my informants, who described it in terms of a relationship - sometimes cooperative, sometimes oppressive - between Whites and Congolese people. $^{2}$ The word people use to talk about Whites in Swahili, bazungu in the plural, is sometimes metaphorically extended to well-off Black people, not because they are confounded with Whites, but because they share their modern lifestyle (kizungu). ${ }^{3}$ In the accounts that people in HautKatanga gave of their history, however, the category bazungu referred unambiguously to Whites. While talking about bazungu in such contexts, my informants explicitly made reference to their skin colour, or to their national identity (Belgians, Americans, Italians, etc.).

I thought at first that these historical accounts in black and white derived from the situation (a dialogue with a Belgian anthropologist) and the subject of our conversation (the image of White people). However, I realised that references to these stories were also made in discussions on other topics and in interviews with my Congolese assistants. Outside the formal research setting, they arose spontaneously whenever the conversation turned to public matters (politics, labour, public health, etc.), whether in cities or in villages, over a beer in a bar or at home. It is the pervasiveness of these discourses that led me to study the affinity between racial/national identity and post-colonial memory. ${ }^{4}$

The history of Congo since independence has been affected by the patrimonialisation of the state, the decline of the industrial economy, and a succession of conflicts, which plunged the population into poverty and hardship. This article focuses on the accounts in black and white that people in Haut-Katanga give of this tragedy. Four different stories can be distinguished on the basis of their narrative structure and historical genealogy: the abandonment of Congo by Belgium, the biblical curse on Africans, the alienation of power spirits, and the conspiracy of Western capitalism; but all four stories consider the destiny of Congo as depending on the intervention of Whites.

Though this article is not based on a systematic collection of memories, it is supported by strong evidence collected between 1999 and 2006. During this period, I conducted research on relations between Lamba townsmen and countrymen, on the careers of doctors who graduated from the University of Lubumbashi, and on the economic and political role of the White community. In 2006, I started a new piece of fieldwork on the future of the former workers of Gécamines in Likasi. The four accounts discussed in this article arise in many of the 300 formal interviews with Congolese people that my assistants and I recorded while carrying out 
these different research projects. However, in order to emphasise the spontaneous and situational character of the four stories, most examples below have been taken from casual conversations. Compared with formal interviews, opinions articulated in such contexts offer the advantage of not having been provoked by the researcher.

A B RIEF HISTORY OF HAUT-KATANGA

Haut-Katanga is situated on a geological stratum rich in copper, cobalt and zinc, which forms a belt from Kolwezi to Lubumbashi. Between the Atlantic and the Indian oceans, it was hit late - but violently - by the slave trade, when its control fell into the hands of warlords in the middle of the nineteenth century (Legros I994; Miller 1988). In comparison with the kingdom of Kongo, its conquest by imperialist powers was also belated, as it was subjected to colonial rule only at the turn of the twentieth century. The region was spared by King Leopold II's rubber regime, and had to wait for the Congo to be handed over to Belgium in I908 to witness the advent of industrial Haut-Katanga's two main pillars: the mine and the railway. However, its future was still uncertain at that time, because it remained short of capital and labour until I920 (Fetter I976).

From 1920 to 1960 , industrial expansion, development of urban facilities and an increase in welfare services caused a rapid growth and relative stabilisation of the urban population (Fetter 1976; Higginson 1989; Perrings 1979). In cities, most Africans depended on wage labour, which involved, at the eve of independence, $90 \%$ of the working population (Benoît I96I). At that time, rural-urban immigration no longer required administrative constraint. It was the product of an economic, social and cultural attraction for the city as the location of 'modernity'.

In I960, the mutiny of the army enabled Moïse Tshombe to declare the secession of Haut-Katanga, before being defeated by UN troops in 1963 (Gérard-Libois 1963). After his coup in 1965, Mobutu progressively reunified the country and brought prosperity to Haut-Katanga. However, this euphoric boom quickly ran out of steam after I975. Gécamines encountered economic difficulties after the fall in copper prices and the breakdown of the Benguela railway in Angola. ${ }^{5}$ The nationalisation of foreign companies by the regime resulted in a fall in employment in the private sector, and a shortage of goods on the market (Turner \& Young I985). Facing budget recession and galloping inflation, the regime was forced to accept the structural adjustment programme imposed by the Bretton Woods institutions. 
The situation was aggravated after the end of the Cold War, as this induced funding corporations and cooperation agencies to withdraw from Zaïre. During the same period, Gécamines experienced a new crisis and found itself in insolvency, which threw local suppliers into bankruptcy. The growing shortage of wealth and foreign pressure then forced Mobutu to tolerate multipartism. This decision to liberalise political activity led to a period of 'transition' (I99I-7) characterised by a struggle between two factions (de Villers \& Omasombo 1997). These rivalries constituted the context of the tragedies to which the inhabitants of Haut-Katanga were subjected in the I990s, namely the looting of inner cities by the army in I99I, the violent deportation of Kasaians between 1992 and I993, and a four-figure rate of inflation in 1993 and I994.

If Laurent-Desiré Kabila's accession to power in I997 brought a glimmer of hope to Haut-Katanga, this was disappointed a year later when the war against Rwanda and Uganda broke out. The war divided the province in two and generated an influx of refugees from the north. It also led the new regime to impose a fixed exchange rate and to grant mines to businessmen in Mugabe's entourage, in return for support from Zimbabwe (Nest 200I). In I999, belligerent parties started negotiations, which merely culminated in an effective lull three years later, after Kabila's murder. These parties then set up a transitional government awaiting the organisation of elections in 2006. It remains to be seen, now, whether the winner of those elections, Joseph Kabila, will succeed in restoring economic and political stability.

In short, the post-colonial period has been characterised, in HautKatanga, by the collapse of industries, the closure of manufacturers, a decrease in trade and the bankruptcy of the state. This process of recession caused a fall in employment and wages, which resulted in a boom in public service corruption, the proliferation of small-scale activities, and a recolonisation of the rural hinterland (Bruneau \& Pain 1990; Petit 2003a). Whereas this small market economy formerly evolved in the shadow of the large mining industry, it now hinges on the private sector, which is dominated by foreign entrepreneurs.

It is important to note that, though their number has decreased from 30,000 to I,500 since 1960, Belgians, Greeks and Italians have remained a rich racially bounded community in Lubumbashi (see Rubbers 2006a). Having held top positions in big industry when it was the major force in Haut-Katanga, they captured the most profitable sectors of the economy (mining, import trade and transport), together with Indian and Chinese competitors. Their success in reproducing their economic dominance and racial insularity since independence confers on 
Lubumbashi a (neo-colonial) atmosphere very different from that in Kinshasa.

How do the people of Haut-Katanga remember this history? Following Jewsiewicki's (I986; I99I; I996; 2003) and Fabian's (Fabian \& SzombatiFabian 1976; Fabian 1978, 1996, 1998) pioneer work on popular painting and memory in Katanga, this article aims to bring further light on the role of narratives and stereotypes in the construction of post-colonial memories. To study memory, Jewsiewicki and Fabian confront the representations of the past (events, persons, places, etc.) displayed on paintings with the practices and discourses of artists (most popular paintings explicitly intend to evoke thoughts about the past). Memory is primarily conceived, in this context, as a performance - that is, a process inseparable from painting. In return, doubts are expressed about the narration of memory in Haut-Katanga (see, e.g., Fabian I996: 269-96; Jewsiewicki 2005). Of course, paintings and objects generally provoke thoughts about events, persons, places, not narratives about history. But Jewsiewicki and Fabian resort to a more general explanation according to which historical narration presupposes the state as moral subject: 'the problem popular historiography has with being coherent and systematic may reflect practical, and realistic, problems with acknowledging the state as a reality' (Fabian I996: 270; Jewsiewicki 2002: 593-8).

Contradicting this thesis, the next section shows that people in HautKatanga do have schemas to recount their national history, and suggests that these schemas are not related to abstract conceptions of the state, but to various 'discourses' of historical significance in this region: colonial propaganda, the Bible, rumours about Whites, and nationalism. By contrast with Jewsiewicki and Fabian, this article deals with interpretations (stories), not representations of the past (moments). I am interested in how people connect and structure events in narratives to account for the present situation. And my concern is not with the discourse of one artist or group of artists, or their work, but with the different historical interpretations existing within the population of Lubumbashi.

This approach led me to stress the role of Whites in the construction of national memories. Though this category is often used in this society deeply affected by colonialism and racism, it is rarely mentioned and discussed in the works of Jewsiewicki and Fabian. One could interpret this absence by the fact that, if Whites are frequently represented on paintings, the conversation with artists was brought around to historical situations, not to the forces of history. Whereas Whites are rather marginal in memories about particular events after independence, they are central in interpretations of historical sequences. And, as we will see in the next 
section, their role in such interpretations is not necessarily conceived as negative.

IN TERPRETATIONS OF POST-COL ONIAL H IS TOR Y First interpretation: the abandonment by Belgium

Relations between Whites and Congolese people in Haut-Katanga are underlain by a norm of asymmetric reciprocity, which demands that Whites support the poor, and that Congolese people adopt an attitude of submission and circumspection (Rubbers 2006a: I63-219). ${ }^{6}$ The former coloniser holds a distinctive position in this power constellation, not only because he represents the 'authentic' expression of whiteness, ${ }^{7}$ but also because he is considered as a father. ${ }^{8}$ This metaphoric kinship allows many people of Haut-Katanga to blame Belgians for their paternal abdication. They remind us that Belgium got them out of 'savagery' to pull them up the ladder of civilisation, but then granted them independence too early. While undertaking research in Panda (Likasi), my assistant and I were drinking in a bar, when three Gécamines workers, who were sharing a beer at another table, asked to join us. We started to talk about their new employer, the French Paul Fortain, which was expected to boost Gécamines. This conversation led my interlocutors to express their regret regarding the departure of Belgians from Congo: 'Lumumba was wrong to claim independence', they said. 'It should have taken at least until I990 for the Congolese to reach European level'.

In the opinion of these three Gécamines workers, the colonial authorities abandoned Congolese people to their sad fate, an abdication that makes them responsible for the latter's bad habits. Belgium threw the country over to autocrats, who took advantage of their position to grow rich at the expense of the population. The former metropole also threw the door wide open to the Lebanese, the Indians and the Chinese. All are oiseaux de passage (migratory birds), my informants say, who came to Congo to make a fortune without investing a penny in the country.

Belgium's abdication is not always well understood by the people of Haut-Katanga. It also generates resentment, as a conversation with some Catholic sisters in 2004 makes clear. I was staying with them as a guest at the time, and we often watched television together in the evening, commenting on the news. At that time, demonstrators had destroyed the UN headquarters in Haut-Katanga for having failed to prevent the takeover of Bukavu by pro-Rwanda rebel General Nkunda. The sisters strongly supported the protest and even suggested that similar action should 
be undertaken with Belgium's representative offices. In their opinion, Belgium should intervene militarily against any foreign attack, exactly as the United States freed Europe from Nazi rule.

The reason for this bitterness and resentment is that, from my informants' point of view, colonisation was a promise for good. ${ }^{9}$ Although guilty of its abdication, Belgium is still bound by the indissoluble ties of kinship, which force her to fulfil her obligations to Congo. It is Belgium's business, therefore, to raise Congo out of despair and to set the country back on the tracks of development and democracy. Take, for example, the tearful plea of this 3o-year-old forwarding agent at Kasumbalesa border, with whom I got in touch thanks to a colleague at the University of Lubumbashi. We met in a bar in Lubumbashi to talk about the different ways of enabling goods to pass across the Zambian border (see Rubbers 2007). At the end of our conversation, he said that, now that he had answered my questions, he wanted to express his opinion concerning the relationship between Belgium and Congo. Here is an extract from his long monologue:

All we have here has been given to us by Belgians. You crafted our life [sic] ... You shouldn't have granted us independence. With the Congo, you could have become the first great power of the world. You must come back. We are waiting for you. We claimed independence, it is true, but independence doesn't mean our relationship is broken. Do you abandon your child when he wants to leave? No. He'll become an adult but he'll still need his parents to find the right direction in life. You cannot abandon your children like that!

Even though such a plea would have been defined as heretical at the time of decolonisation, it began to circulate in the streets of HautKatanga's cities during the ig8os. It became even more common following the withdrawal of funding agencies, the collapse of big companies, and the socio-political troubles of the ig9os. In 2004, President Joseph Kabila himself celebrated the work of Belgium in Congo. 'The history of the Democratic Republic of Congo', he told a large audience in Brussels, 'is also the Belgians' history - missionaries, administrators and entrepreneurs - who believed in the dream of King Leopold II to build, at the heart of Africa, a state. We want to pay homage to all these pioneers' (Kabila: 2004).

Historically, if this rhetoric dates back at least to the setting up of paternalist policies in the I920s, it gained new resonance after the Second World War. At that time, economic growth allowed the Belgian authorities to re-articulate their legitimating discourse regarding the expansion of facilities (industries, camps, roads, etc.) and the welfare of the colonised (Jewsiewicki I976). In colonial imagery, the Congolese were represented as 
smiling, proud of their lot, surrounded by the symbols of modernity. These images illustrating the benefits of colonisation embodied a meta-discourse ('dominate to serve') specifying the civilising mission of Belgium in Congo. Belgium was not in Congo to exploit the colonised, it was asserted, but to lead the natives on the road to progress. In return for this unreciprocable gift, the Congolese were expected to show gratitude to their benefactor. As Belgium saved them from barbarity, they would be eternally indebted to her (see, e.g., Coppens I934: 5).

\section{Second interpretation: the biblical curse on Africans}

In the first interpretation given above, people of Haut-Katanga reuse, one could say, the narrative structure of the prodigal son parable (Luke $\left.\mathrm{I}_{5}: \mathrm{II}^{-} 3^{2}\right)$ in order to reconstruct the history of their country. But in the retold version, the story ends quite differently, thereby allowing the Congolese to call for the help of Belgium. People in Haut-Katanga prefer to cite another biblical reference, the passage where Africans are said to originate from Ham. ${ }^{10}$ Whether they belong to the Catholic or to Pentecostal churches, my informants' reading of this passage attributes Whites' fortune to their divine election and Congolese' misfortune to their curse. During an informal conversation with a (Pentecostalist) colleague at the University of Lubumbashi, I asked him why Whites were sometimes called by the nickname mutoto wa Maria (Child of Mary). His answer was: 'For us, God is White and He is at the service of White people. He is not there for Black people.'

The incorporation of both Whites and Congolese people in a divine order makes sense, for people in Haut-Katanga, of their respective qualities. As interviews on racial perception show, they emphasise Whites' honesty, organisation, gentleness and compassion, in contrast with Congolese corruption, disorder, harshness and individualism. In their view, these traits do not derive from society, but from an atavism of biblical origin. After a football match in Lubumbashi, a friend and I went in a bar for a drink, when a soldier suddenly interrupted our conversation. He wanted to warn me against his compatriots: 'The Black man has a black soul. We, the Congolese, we don't like each other; to hurt someone else, to see him suffering, it gives us joy. We have no love, no feelings, for other people. We have $2 \%$, maximum Io $\%$, of love. As for the White man, he has at least $50 \%$ of love.' This is because Whites are, in his opinion, the favourite children of God.

This way of seeing Whites and Congolese people attests the powerful cultural influence of missions, which were granted a monopoly over 
the education of Congolese children during the colonial period. Indeed, the Belgian administration considered that the disciplining of natives implied, as in the case of the working class at home, inculcation of the rudimentary precepts of Christianity (Stengers 1989: 195). On the eve of independence, Congo was covered by a network of 669 Catholic missions, employing 6,000 missionaries and 25,000 catechists. The country then numbered more than 5 million converts (80\% Catholics), while school enrolments exceeded Io $\%$ of the total population, as against $3 \%$ in West Africa (Young 1965: 12-I3). On the other hand, the administration distrusted protestant missions: it was suspicious of their loyalty towards the Belgian colonial cause, and regarded their religious doctrine as likely to encourage subversion among the colonised. For that reason Protestant schools waited for the end of World War II, and the liberation of Belgium by American troops, to receive funds from the colonial state.

At least until the I93os, Catholic missionaries used the alleged curse on Ham to give biblical legitimacy to racist theories prevailing in the first half of the twentieth century. The struggle against slavery and the colonisation of Congo were represented, in evangelists' texts, as a mission with which God entrusted King Leopold II and Belgium (see, for example, the school-book songs reproduced in Vinck I999). Colonisers had been chosen to save the Congolese people from Noah's curse, and should be thanked for this self-sacrifice. The colonised people were to show them submission and respect at the risk of repeating their ancestor's fault, the one at the origin of their dismissal. One can recognise in missionary teachings, therefore, the moral principle underlying colonial propaganda in general, which encouraged natives (children) to honour their civiliser (father). But here the force confronting Congolese existence with a choice between happiness and unhappiness is no longer human, but divine. Their indiscipline would therefore ineluctably condemn them to interminable suffering.

From the people of Haut-Katanga's point of view, this warning was to be taken seriously, since immediately after independence, chaos fell upon the entire country. The poverty into which they have sunk since ig6o reminds them of the curse hanging over their fate. They are thus confirmed in the belief that there is no salvation without White support. This opinion is not contradicted by the Pentecostal churches that grew in number in the Ig9os. Many pastors emphasise the crucial importance of receiving God's blessing to succeed in life, and claim that the Whites' fortune derives from their devotion. After all, lots of Pentecostal videos, tapes and reviews come from the United States. 
Third interpretation: the conspiracy of Western capitalism

Another story emerges when people in Haut-Katanga use the lexicon of dependency theory in order to read the history of their country, charging international capitalism and the national bourgeoisie with all its evils. In this world-view, the fortune of Whites is made possible by the exploitation of Africans. At a dinner in a friend's home, we were joined by one of his friends, who reported his experience as an engineer in a Greek company. He earned US \$I3o per month, which was much more than the average income of university graduates in Haut-Katanga, but much less than he expected: 'They pay small negroes nothing', he said, 'while they line their own pockets.' And this abuse of the workers was allowed to continue, in his opinion, due to the corruption of the political elite: 'They [Whites] are above the law', he went on, 'because they have our leaders in their pocket.'

Whites are thus famed for their shameless greed. As an administrative authority claimed during an informal exchange on the role of expatriate entrepreneurs, 'No morality can be expected from them because their unique aim is to take advantage of the situation.' It is this rapacity that drives them to come to Congo and to loot its riches at the expense of the Congolese people. Therefore nobody believes them when they justify their presence by altruistic (to help the population) or intellectual (to undertake scientific research) arguments. Indeed, during a conversation in a bar about cooperation with Belgian universities, a lecturer at the University of Lubumbashi considered that 'they [Belgians] cannot be releasing all those funds for nothing. They must be getting something out of it!' Their activities must inevitably be motivated by economic ends.

This critical paradigm constitutes a conspiracy theory that recognises the invisible hand of imperialism behind the hardship of life. It is therefore as ethnocentric as colonialism itself, since both deny any agency on the part of African societies. Brought down by the three periods of slavery, colonisation and dependence, Africans' history is reduced to the intervention of the West. Instead of building their future, Africans are passively submitted to the fate that White people have prepared for them: 'Ultimately', Mbembe (2002: 252) argues, 'the African is supposed to be [in such conspiracy theories] merely a castrated subject, the passive instrument of the Other's enjoyment.'

In Congo/Zaïre, criticism of imperialist exploitation on the public scene emerged spectacularly during Lumumba's speech on the day of independence, in the presence of King Baudouin. ${ }^{11}$ After Lumumba's assassination, this critical approach was taken over by Mobutu, who adopted 
it in order to promote Zaïrian 'authenticity', and justify the nationalisation of foreign businesses in the I970s (see Mobutu I970). The subjugation of Congo/Zaïre was responded to, after the coup of ig65, by the exaltation of the nation and the idealisation of her guide (see Turner \& Young I985). ${ }^{\mathbf{1 2}}$ After a long period of silence, Third Worldist ideology was imposed anew on Congolese society, when Laurent Kabila gained power in I997. In his famous address at the Palais du peuple in I999 (Kabila I999), he denounced the support brought by imperialist interests to the Mobutu regime and developed a revolutionary rhetoric, promising the end of neocolonialism and the promotion of the empowerment of the people.

This populist discourse met with a fair amount of success among the inhabitants of Haut-Katanga after thirty years of Mobutism. But Congo was soon to be attacked by Rwanda and Uganda, two foreign powers, an attack allegedly masterminded by the United States. And when Kabila himself was murdered in 200I, as Lumumba had been forty years earlier, many people in Haut-Katanga believed that they were again being submitted to Western 'protection'. After the publication of a paper on my research on racism at the University of Lubumbashi, the sociologist Olivier Kahola spontaneously sent me an e-mail to offer his analysis:

On the political level, the accession of L.-D. Kabila to power had given rise to another image of White people. The late president always professed White people could do nothing against the Congolese. His assassination proved for us that the Whites always want to appear as saviours to the Blacks, and never want the Blacks to free themselves from their hold. As soon as Black people take some independence, Western people destabilize them by wars and murders in order to remain the invisible masters of the world. That is what makes people wonder why African nationalists never last, but end in tragic deaths.

This desperate opinion has not been contradicted by the recent elections, which have been heavily funded and organised by the United Nations and the European Union. Indeed, a large number of my informants are convinced that the poll was a kind of masquerade aimed at putting Joseph Kabila, the West's favourite, into power.

\section{Fourth interpretation: the alienation of life powers}

Finally, people may read Congo's history not through colonial or anticolonial lenses, but through the indigenous theory that explains the fons et origo of wealth through mastery over occult forces (see Auslander I993; Comaroff \& Comaroff I999; Geschiere I997). From this point of view, Whites are the cause of the Congolese people's misfortune. This is demonstrated by Petit $(2003 \mathrm{~b})$ in an article on the Luba of northern 
Haut-Katanga: 'White people have alienated', he shows, 'the different types of spirits on which Luba welfare rests.' After transgressing the rules associated with the spirits guaranteeing natural fecundity (mines, fields, rivers, etc.), Whites subjugated them to work on their behalf. Missionaries banned rituals dedicated to ancestors, who are believed to protect the welfare of the household, and seized their power by gathering the dead in cemeteries. The missionaries also fought mediums who could communicate with trance 'spirits' and give protective charms. Of these power objects, statuettes were burnt (auto-da-fé) or stolen to be sold on the international market.

From this perspective, Whites' opulence derives from the power of their spirits - a power demonstrated by the extraordinary goods imported from the West - and from their capacity to master the spirits in Africa. Accordingly, the presence of Whites is not always seen as innocent: their guests may suspect them of trying to steal the power spirits securing their own living. For this reason, as I have experienced myself in Lambaland, visitors in rural areas sometimes become the target of rumours as to how they have come to take possession of mineral riches and ritual statuettes.

This interpretation seems restricted to people with a low educational level living in rural areas or in suburbs. In interviews with school-educated urbanites, few referred to the existence of spirits, and those who did only associated them with natural resources in the 'bush'. No mention was made of Whites' spirits. Nevertheless some alluded to Whites' invincibility to witchcraft, magic practices (evidenced by fantasy and horror films) and occult associations (the order of Freemasons or the Rosicrucians). In all cases Whites were credited with supernatural powers explaining the supremacy of their science and technique.

In this repertoire is also found the figure of simba ya Bulaya (the lion of Europe), the White man who eats Congolese people. He recruits batumbula (native auxiliaries) - recognisable in popular paintings by their coat, their hat, their torch and their dark glasses - to kidnap men and women in remote places and to confine them in some prison (pit, cellar, attic, etc.). There, victims are fattened with salt until they see hairs growing on their body and they turn into pigs. Unless they put them into cans, White people, along with their guests, will consume them at Easter, Christmas or New Year.

Two hypotheses, albeit compatible ones, are put forward regarding the origin of such stories, which have been reported over a very large area in central Africa. In a reference article, Ceyssens (1975) suggests that the appearance of the stories dates back to the beginning of the slave trade, when Africans were taken far away, never to return to their own country. 
A number of missionaries and explorers give evidence, from that period to the time of the colonial conquest, for the wide geographical extension of the belief according to which goods imported from the West were actually manufactured from the slaves captured in Africa (oil, corned beef, gun powder, etc.). Pels (1992) offers another interpretation, which locates the source of mumiani (vampire) stories in India, where it was rumoured that the blood of sick people was used in hospitals to make a drug called momiyai, which was widespread at the end of the nineteenth century. The rumour would have been introduced later into Africa by soldiers and traders, and propagated in British colonies.

As White (2000) points out, this genetic approach does not account for the longevity and periodicity of these stories. It emphasises the origins of the stories, but overlooks the differences, and turns a blind eye to the conditions of their resurgence. However, their content changes in time and space, as the stories always reflect experiences situated in local constellations: the stories of twentieth-century workers and those of nineteenth-century slaves were different because they addressed two different power systems. Therefore, if these stories rework old narrative patterns (witchcraft, zoomorphism, anthropophagy, etc.), they above all constitute a new idiom with which to talk about new relations in a new social order (ibid.). Rumours regarding batumbula in Haut-Katanga during the colonial period, for example, may be related to the experience of migration into industrial cities. As the casting of roles in these stories gives plenty to think about, they seem to offer an allegorical comment on various aspects of urban life such as work hierarchy, camp discipline, the symbolic power of dress and the politics of marriage.

Today, the old still pass on memories of the White ogre to younger generations, saying that they themselves only just escaped seizure by his subordinates. During a visit to a former Gécamines worker, for example, he related - at my request - what everyday life had been like in the compound under colonial rule. To his two young daughters, he explained that, when he was a child, his parents forbade him to go outside the compound at night: he could be attacked by batumbula and disappear forever.

People talking about batumbula generally reposition their anecdotes in the colonial past, pointing out that vampires have ceased to exist since White people left in ig6o. However, these rumours are liable to resurface wherever a White man turns up with obscure intentions in a rural area. This was what happened at the beginning of the I99os when the anthropologist Petit (2003b) was accused of trying to exchange his car for children in Kabongo, northern Haut-Katanga. From the people of HautKatanga's point of view, although the likelihood of seeing vampires 
re-appear is slight since independence, it is not impossible. This idiom therefore maintains some weight in making sense of Whites' presence: the fortuitous return of one of them is enough to make people cross the border again between the genres of story-telling (past) and rumour-telling (present).

The use of stories about spirits, supernatural powers and vampires to make sense of post-colonial history is unusual in Haut-Katanga. In interviews, this discourse - the alienation of life powers - arose less often than those of the abandonment by Belgium, the biblical curse on Africans, or the conspiracy of Western capitalism. Nevertheless, since my analysis is not based on a statistical sample, I choose to put it on the same level as others. My aim is to find evidence for all possible interpretations of Congolese history using a racial/national schema, whatever their rate of recurrence, and to study their social conditions of emergence (see Glaser \& Strauss I967). As we will see, the four stories are to be associated less with categories of people than with interaction settings.

A D UALISTIC CONCEPTION OF THE WEST

\section{Two contrasting scenarios}

The four stories give valuable interpretations of post-colonial history, but resort to hidden scripts whose existence cannot be controlled empirically. ${ }^{13}$ Accordingly, trying to decide whether they offer a true or false representation of the past is pointless; what really matters is the narrators' degree of adhesion to their 'myths' (Veyne 1998 [1983]). As far as I can tell, my respondents' conviction in their interpretation of history was sincere, whether they intended to praise or to criticise colonialism. Nevertheless, a major contradiction between stories of the abandonment by Belgium and the biblical curse on Africans, on the one hand, and those of the conspiracy of Western capitalism and the alienation of life powers, on the other, leave room for ambiguity.

One might expect this contradiction to end up weakening their respective validity, dissolving social meaning (loss of reality) and creating a cognitive divide (cleavage of the self), finally resulting in schizophrenia. This psychoanalytic interpretation has been followed by De Boeck (I998), who claims that Congolese people are caught up in an unsolvable contradiction between 'tradition' and 'modernity'. However, contradiction in lines of action or discourse will not generate psychic splitting and suffering as long as they are not enacted in the same context (Lahire 2001: 47). Regarding emic histories of Congo, circumstances obviously foster or inhibit the use of one particular explanation. 
With the exception of stories about power spirits, the four historical explanations above are not exclusively associated with a given place, a particular social category, or a specific domain of action. They are expressed in cities and villages, with outsiders and with relatives, by rich businessmen and political leaders as well as by the multitude of workers, farmers and petty traders. It even happens that conflicting interpretations are advocated by the same person, one after the other, in the same conversation.

In facing the logical dilemma towards which their interpretations lead, people succeed in resolving this reflexively by regarding the White man as an ambiguous being: he is both good and evil. He is represented as a source of power and danger, arousing feelings of fascination and terror, wonder and shame, respect and rejection (compare with Nyamnjoh \& Page 2002). Therefore the heterogeneity of explanations does not question the illusion of cohesion constitutive of subjects' identity. On the contrary, it offers flexible accounts of their present-day life, and therefore provides them with several keys with which to master their future symbolically.

To what extent are these stories shared by the inhabitants of HautKatanga? Taking up Halbwachs's work (I992 [1925]), social scientists in the last two decades have studied the social frameworks through which memory is collectively built (see Olick \& Robbins 1998). It is now acknowledged that, if memories are individual, they are never enacted in isolation, but in a given (material and social) context. Their social transmission comes to constitute what Zerubavel (I996) calls 'mnemonic communities'. In Haut-Katanga, my respondents did not always mention the same events, and they also remembered them differently. However, they used a limited number of historical genres in order to lump these events together into stories. In other words, they shared memories about the past less than they did narrative structures with which to interpret this past diachronically. In associating the past with the present, memory operates through narratives that impose an illusion of coherence upon the unpredictable succession of events (Antze \& Lambek i996: xvi-xix). These narratives follow conventions existing in limited number, which both constrain and authorise memory. ${ }^{14}$

\section{Time, culture and power}

What exactly do the four accounts teach about their narrators' conception of history, culture and power? With regard to history, discourses relating to exploitation and alienation place the post-colonial tragedy within the continuity of colonial terror and of the slave trade, showing ruptures in the 
course of time as only indicating changes in the way external powers subjugate Africans. The discourses relating to abandonment and curse, however, draw a clear line between the colonial Eden and the postcolonial hell. This does not imply, however, that people think of the period after independence as a homogeneous span of time. It means only that they consider it as a continuous process of decline, though one that is crossed by multiple temporalities.

This cleavage between continuity and rupture matches two contrasting moral assessments of colonisation as a cultural project. The accounts in terms of abandonment and curse sustain expressions of colonial nostalgia, a form of reminiscence echoing feelings of sorrow and despair in the present (Rubbers 2008). They give evidence for the powerful influence of the 'colonisation of consciousness' in Haut-Katanga (Comaroff \& Comaroff I99I). The inhabitants of this region have, to a large degree, internalised the view that colonialists had of their cultures, and therefore borrow the West's categories of thought in thinking about themselves (Chrétien \& Triaud i999).

Accounts of history in terms of exploitation and alienation nevertheless show that colonial hegemony remains incomplete in Haut-Katanga. Indeed the discourse regarding alienation challenges the positive portrayal of colonisation by using a cultural code (modernity as witchcraft) which disputes the Western, anthropocentric, and voluntarist, moral economy of progress: it depicts a world where the process of production is controlled not by human beings but by supernatural powers, and where one's profits are always gained at the expense of others (see Austen i993). Development is accordingly regarded as a strategy of occult despoliation. As for the rhetoric of exploitation, if it borrows its vocabulary from a Western ideology, it attests first and foremost the deep impact of nationalist (anticolonial) ideologies following independence. Although the power balance between Africa and Europe remains identical, this discourse reverses the moral value of each pole to represent colonisers as executioners (rather than heroes), natives as victims (rather than savages), and colonisation as a machine of oppression (rather than a work of civilisation).

This dualistic conception of the West also structures the moral perception of the White man, the dominant character of the four stories. The narratives of abandonment and curse show that, far from condemning the symbolic violence of colonial racism, many people in Haut-Katanga take responsibility for it by representing Whites and Blacks as two antonymic poles. In this region, the alleged nature of the Whites grants them the favours of the little man for managing institutions, to the detriment of Congolese managers. A case in point is this worker's verbal attack, 
reported by a friend, against a Congolese manager at the head office of Gécamines in 2004: 'You, you cannot manage. You are only interested in eating money. Appoint a White man at the head of the company! Go and take some vagrant in the street in Europe, even a ten-year-old child, and appoint him to do the top job. You will see: the company will run, we will work and all will be again as it was before.' The reverse of this asymmetric mirror is offered by theories that explain racial inequality by the exploitation of workers and the alienation of life powers. In this predatory conception of race relations, White people are purportedly ready to use occult means, to bribe rulers, and to enslave masses to quench their thirst for money. Their power implies the symbolic murder of Congolese people.

The White man is represented, as I have already shown, as an ambiguous being, sometimes beneficent, sometimes maleficent. However opposite, the two images grant him absolute power, in contrast with the helplessness of Congolese people. In all four discourses, the White man is the sole entity responsible for the country's downfall. In other words, if the four accounts above take different views of the relationship between racial/national identity and history, they fit within the same paradigm of domination: Congo is a blank page on which the West writes History. At the heart of their hermeneutic of power lie the imaginings of race and nation so that Congolese history is always told as the enactment of White people's power.

\section{Identity and memory}

How can we explain the racial/national framework of all four stories? At first glance, skin colour seems to function as a social framework of collective memory - that is, a mnemonic device causing the narration of such stories. But these stories are not confined to interracial contexts, and must therefore have more intimate links to racial/national imagining. Indeed, they have a racial/national dimension themselves because they have been, from the start, closely associated with colonial or anti-colonial ideologies couched in racial/national terms. People continue to use the narrative conventions of these ideologies in remembering the past. Memory and identity are not simply constructions of and for the present, but are also influenced by the politics of the past (see Appadurai i98i; Peel I984).

Besides their common roots in the past, memory of the post-colonial past and racial/national identity in Haut-Katanga can be considered as reciprocally constitutive (see Antze \& Lambek 1996). Racial/national identity makes sense of past vicissitudes and present difficulties evoked in these stories; it gives an ontological explanation to the success of White 
people and the failure of Congolese people. In return, racial/national stereotypes are themselves confirmed through everyday anecdotes and historical reconstructions. The tragedy of Congo since ig6o is interpreted by people in Haut-Katanga as proof of their own 'congenital inability to rule the country' - to quote the expression of a Congolese journalist (La Tribune 5.6.2003: I).

It is racial/national identity, one could say, that gives to the four stories their political power. Through their racial/national frame, they subject the Congolese in both senses of the word: they subjugate them (through their content), by crafting their subjectivities, and they allow them to act as subjects (through their use). Here lies perhaps the paradox of our four discourses. On the one hand, they may be seen as an ideology in the Marxian sense: an 'opium' forcing the Congolese masses to accept their sad fate by rooting their powerlessness in nature. On the other, they may be part of discursive tactics aiming at changing the power balance between Congolese and White peoples.

The narrative regarding the abandonment by Belgium exploits development ideology, which conceives of the relationship between the West and Africa as a relationship between saviour and victim. It also reminds Belgium of her promise to lead Congo on the road to civilisation. It may therefore be part of an extraversion strategy which takes advantage of Congo's dependence on the West (see Bayart 1993). Conversely, the discourse regarding the conspiracy of Western capitalism necessarily implies a kind of liberation theology: Third World 'victimology' undertakes to free the people from the chains of foreign oppression, to restore national integrity, and to lead the country on the road to prosperity. By representing White people as a threat, it seeks to strengthen people's national sense of belonging, and to justify the seizure and/or exclusion of foreign interests. Evidence for the use of this discourse in the scope of a nationalist strategy against Western influence has been given by Lumumba, Mobutu and Laurent-Désire Kabila.

The discourses regarding the curse on Africans and the alienation of life powers do not seem to bear any relation to action. However, as a book of symbols and parables open to various interpretations, the Bible allows not only the reconstruction of the past, but also the scrutiny of the present and the anticipation of the future. People in Haut-Katanga do not read Noah's curse upon them as a divine law engraved on human bodies for all eternity. On the contrary, the Bible leaves hope for a deep and lasting change, as the condition for regaining God's mercy. This message was clear in the missionaries' teachings during the colonial period. Now mundane salvation through rupture with the past and strong individual 
piety is strongly promoted by Pentecostal churches (see Marshall-Fratani \& Péclard 2002). And in order to encourage the congregation towards more religious fervour, pastors sometimes claim that the fortune of Whites derives from their greater faith in God. The discourse regarding Noah's curse may thus be included in a broader strategy of reforming the Self - i.e. the individual self and the self of the nation.

By contrast, the discourse regarding occult powers shows White people to be the cause of Congolese people's alienation for having diverted them from their 'tradition'. It can therefore be used in a traditionalist strategy calling for the rejection of all Western influence - particularly religion and the return to a 'pure' Congolese culture. Such an ideology was developed by Mobutu in his call for the 'return to authenticity', and has also provided fertile ground for neo-traditionalist movements (see De Boeck I998).

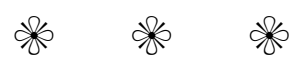

In order to account for the post-colonial history of Congo, people in HautKatanga resort to four different stories, which can be traced back to older discourses about colonisation. The stories of the abdication of Belgium and the curse of Noah bear witness to the continuing influence of colonial ideology until the present day. They represent the White man as a beneficent being and reaffirm the dependence of Congo on the West. Conversely, the discourses regarding the conspiracy of the West and the alienation of life forces by White people give evidence for the limits of colonial hegemony. They look on the White man as a maleficent being and demand the emancipation of Congo from the West.

Though the four stories differ, they portray the White man as the unique source of agency in history. To make sense of this racial/national framework, I have developed the idea that the narrative conventions through which memory operates influence not only the type of scenario, but also the type of actors taken into account. The racial/national dimension of these stories derives historically from the colonial and anticolonial discourses that had an impact on the history of Haut-Katanga. These ideologies, rumours, or representations offer racial/national philosophies of history that have now been taken up in the construction of postcolonial memories.

Today, racial/national identity and post-colonial memory are involved in a reciprocal and constitutive relationship. On the one hand, the four stories presented here give weight to racial/national identity by stressing its continuity and cohesion in history: collective history is considered as a 
racial/national destiny. On the other, they are supported by stereotypes about the relative fortune of White people and Congolese people: collective memory is influenced by racial/national identity. Associating arguments regarding post-colonial history and racial/national identity, the four accounts can be considered as a strategic toolbox, giving people the opportunity to claim help or reparation from the West. Although their ideological content tends to lock the Congolese into fatalism, their practical use allows the latter to act as subjects and to create a better future.

\section{NOTES}

I. Words such as White or Black are used here as emic constructions (i.e. cultural representations held by informants) not as biological categories. For ease of reading, they are not, however, put in inverted commas.

2. This article is about how people in Haut-Katanga remember their national history, not their regional history. My argument is that, to account for the history of Congo as a whole, they generally refer to the Congolese/White dichotomy. This is not the case when the conversation turns to the history of Katanga. In such a situation, they are more liable to use the opposition between 'Katangese' and 'Kasaian' people, or between the capital city and the province.

3. Fabian (I995: 43) suggests that the term muzungu 'distinguishes one class of non-Africans (there are others) on the bases of origin, socio-economic status, and political position, but not of color'. In fact, this word is often used to talk about Africans, Africans living in the West, or rich Africans living in Congolese cities. But this use is metaphorical: people generally say muzungu for White and only use the same term for non-Whites analogically. In the note following his interpretation of muzungu, Fabian (1995: 49) adds: 'This is not to say that Africans such as Kanyemba are "color-blind" - shades and hues of skin color are constantly distinguished and remarked upon. Incidentally, our text contains at least a hint of uncertainty that I failed to notice when I did the translation. At one point the person is referred to as ule kama ni muzungu, a Shaba Swahili idiom signalling a hedge on the part of the speaker.' In my opinion, this idiom (this person is like a White) is not incidental at all.

4. The word 'affinity' denotes a privileged relationship, not a necessity. My argument is not that post-colonial memory is determined by racial/national ideology: people in Haut-Katanga sometimes use other historical explanations, calling into question, for example, inequalities between the elite and the people. What I suggest is that the cleavage between Whites and the Congolese constitutes a privileged key to make sense of the national past in Haut-Katanga, because of its importance in the economic and social history of this region.

5. Gécamines was the name given to Union Minière du Haut-Katanga after nationalisation in I967. This huge mining corporation was, from I9Io to I986, the pace-setter of the regional economy (Rubbers 2006b).

6. This norm is not peculiar to race relations, but characterises most power relations: expectations of Whites are similar to those expressed of 'big men' in Congo.

7. Congolese people distinguish 'authentic' Whites (rich, educated, fair, etc.) from 'second-rate' Whites (poor, mediocre, rude, etc.). Historically, this distinction between two categories of White people derives from the colonial propaganda for protecting the coloniser's prestige from the peril of 'poor Whites' (Vellut I982; see also Stoler 2002). Today, though both categories receive national epithets (the 'true' White is typically Belgian whereas the 'second-rate' White is typically Greek), they do not correspond to real citizenship, but to social and cultural attributes (a rich Greek is liable to be classified as 'Belgian').

8. While the former coloniser is considered as a 'father' in Haut-Katanga, he is assimilated to a 'maternal uncle' (noko) in Kinshasa (see Devisch I994). In the capital city, the majority of the population comes from matrilineal, not patrilineal, societies. Moreover, they have not been influenced by paternalism to the same extent as people in Haut-Katanga.

9. This observation is congruent with Herzfeld's (2005: I49) statement that the object of structural nostalgia takes the form of a damaged reciprocity. 
Io. Ham (Cham) is Noah's son, whose descendants have been cursed because he had shown irreverence to his father, by seeing him naked and drunk in his tent (Genesis 9).

I I. Before i960, freedom of speech was controlled to such an extent that no criticism of colonial rule could overtly arise inside Congo.

I2. A referee rightly reminds us that the construction of a deep sense of nationhood is often conceived by Congolese people as the major achievement of the Mobutu regime. I would add that this national identity has been primarily affirmed, from this era to the present day, in reaction to Western domination and White power. This may explain, to some extent, the resilience of a common sense of belonging despite the dereliction of the State: it would be maintained and exacerbated by the feeling that Congolese people are persistently oppressed and divided by external forces.

I3. On the distinction between memory and history, see Connerton I989; Nora 2002; Ricoeur 2004; Todorov I995.

I4. There is a link here between the operations implied by the construction of individual biography and collective history (on the subject of biography as narrative illusion, see Bourdieu I986; Loriga I996; Passeron I989).

\section{R E F E R E N C E S}

Antze, P. \& M. Lambek. I996. 'Introduction: forecasting the past', in P. Antze \& M. Lambek, eds. Tense Past: cultural essays in trauma and memory. London: Routledge.

Appadurai, A. I98I. 'The past as a scarce resource', Man (NS) I6, 2: 20I-I9.

Auslander, M. I993. " Open the wombs!": the symbolic politics of modern Ngoni witchfinding', in J. \& J. Comaroff, eds. I993. Modernity and its Malcontents: ritual and power in postcolonial Africa. Chicago, IL: Chicago University Press, I67-92.

Austen, R. A. I993. 'The moral economy of witchcraft: an essay in comparative history', in J. \& J. Comaroff, eds. Modernity and its Malcontents: ritual and power in postcolonial Africa. Chicago, IL: Chicago University Press, 89-I Io.

Bayart, J.-F. I993. The State in Africa: the politics of the belly. London: Longman.

Benoît, J. I96I. 'Contribution à l'étude de la population active d'Elisabethville', Problèmes sociaux congolais 54:4-53.

Bourdieu, P. I986. 'L'illusion biographique', Actes de la recherche en sciences sociales 62-3: 69-72.

Bruneau, J.-C. \& M. Pain, eds. I990. Atlas de Lubumbashi. Nanterre: Centre d'Études Géographiques sur l'Afrique Noire.

Ceyssens, R. I975. 'Mutumbula: mythe de l'opprimé', Cultures et développement 7, 3-4: 483-550.

Chrétien, J.-P. \& J.-L. Triaud, eds. 1999. Histoire d'Afrique: les enjeux de mémoire. Paris: Karthala.

Comaroff, J. L. \& J. Comaroff. I991. Of Revelation and Revolution: Christianity, colonialism and consciousness in South Africa, vol. I. Chicago, IL: Chicago University Press.

Comaroff, J. L. \& J. Comaroff. I999. 'Occult economies and the violence of abstraction: notes from the South African postcolony', American Ethnologist 26, 2: 279-303.

Connerton, P. I989. How Societies Remember. Cambridge University Press.

Coppens, P. 1934. Le Colonat Belge au Congo. Bruxelles: Société Belge d'Études et d'Expansion.

De Boeck, F. I998. 'Beyond the grave: history, memory and death in postcolonial Congo/Zaïre', in R. Werbner, ed. Memory and the Postcolony: African anthropology and the critique of power. London: Zed Books, $2 \mathrm{I}-5^{8}$.

de Villers, G. \& J. T. Omasombo. I997. Zaïre: la transition manquée 199o-1997. Paris: L'Harmattan.

Devisch, R. I994. 'Une filiation imaginaire', in G. de Villers, ed. Belgique/Zaire: une histoire en quête d'avenir. Paris: L'Harmattan, 72-6.

Fabian, J. I978. 'Popular culture in Africa: findings and conjectures', Africa 48: $3^{\mathrm{I}} 5^{-34}$.

Fabian, J. 1995. 'Ethnographic misunderstanding and the perils of context', American Anthropologist 97, I : $4 \mathrm{I}^{-} 5^{\mathrm{O}}$.

Fabian, J. 1996. Remembering the Present: painting and popular history in Zaïre. Berkeley, CA: University of California Press.

Fabian, J. 1998. Moments of Freedom: anthropology and popular culture. Charlottesville, VA: University Press of Virginia.

Fabian, J. \& I. Szombati-Fabian. I976. 'Art, history and society: popular painting in Shaba, Zaire', Studies in the Anthropology of Visual Communication 3, I : I-2 I.

Fetter, B. I976. The Creation of Elisabethville (I9IO-I940). Stanford, CA: Hoover Institution Press. 
Gérard-Libois, J. I963. Sécession au Haut-Katanga. Bruxelles: Centre de Recherches et d'Informations Socio-Politiques.

Geschiere, P. 1997. The Modernity of Witchcraft: politics and the occult in postcolonial Africa. Charlottesville, VA: University Press of Virginia.

Glaser, B. G. \& A. L. Strauss. 1967. The Discovery of Grounded Theory: strategies for qualitative method. New York: Aldine.

Halbwachs, M. 1992 [1925]. On Collective Memory. Chicago, IL: Chicago University Press.

Herzfeld, M. 2005. Cultural Intimacy: social poetics in the nation-state. New York: Routledge.

Higginson, J. I989. A Working Class in the Making. Belgian colonial labor policy, private enterprise, and the African mineworker, I907-I95I. Madison, WI: University of Wisconsin Press.

Jewsiewicki, B. 1976. 'L'expérience d'un Etat-Providence en Afrique noire', Historical Reflexions 2: 79-103.

Jewsiewicki, B. 1986. 'Collective memory and its images: popular urban painting in Zaire - a source of "present past", History and Anthropology 2: 365-72.

Jewsiewicki, B. I99I. 'Painting in Zaire: from the invention of the West to representation of social self', in S. Vogel \& I. Ebong, eds. Africa Explores: twentieth-century African art. New York: Center for African Art, I3O- $^{-1}$.

Jewsiewicki, B., ed. 1992. Art Pictural Zaïrois. Sillery, Québec: Septentrion.

Jewsiewicki, B. 1996. 'Corps interdits: la représentation christique de Lumumba comme rédempteur du peuple zairois', Cahiers d'études africaines 36, I4I: II3-42.

Jewsiewicki, B. 2002. 'The subject in Africa: in Foucault's footsteps', Public Culture I4, 3: 593-98.

Jewsiewicki, B. 2003. Mami Wata: la peinture urbaine au Congo. Paris: Gallimard.

Jewsiewicki, B. 2005. 'Travail de mémoire et représentations pour un vivre ensemble: expériences de Lubumbashi', in D. de Lame \& D. Dibwe dia Mwembu, eds. Tout passe: instantanés populaires et traces du passé à Lubumbashi. Paris: L'Harmattan, 27-40.

Kabila, L.-D. 1999. 'Créez partout des comités de pouvoir populaire', available at: < http:// www.deboutcongolais.info/discoursi-cpp.htm >, accessed I3.I.2009.

Kabila, J. 2004. 'Le discours intégral de Kabila devant le Sénat belge', available at: <http:// www.deboutcongolais.info/actualite2/art-97.html >, accessed I3.I.2009.

Lahire, B. 200I. L'Homme Pluriel: les ressorts de l'action. Paris: Nathan.

Legros, H. I994. 'Chasseurs d'ivoire: histoire du royaume yeke (Shaba, Zaïre) des origines à I89I', doctoral thesis, Brussels.

Loriga, S. 1996. 'La biographie comme problème', in J. Revel, ed. Jeux d'Échelle: la micro-analyse à l'expérience. Paris: Gallimard, Le Seuil, 209-3I.

Marshall-Fratani, R. \& D. Péclard. 2002. 'La religion du sujet en Afrique', Politique Africaine 87: 5-19.

Mbembe, A. 2002. 'African modes of self-writing', Public Culture I4, I: 239-73.

Miller, J. G. I988. Way of Death: merchant capitalism and the Angolan slave trade,I730-1830. London: James Currey.

Mobutu, J.-D. i97o. Paroles du Président. Kinshasa: Éditions Zaïre.

Nest, M. 200I. 'Ambitions, profits and loss: Zimbabwean economic involvement in the Democratic Republic of Congo', African Affairs I00, 400: 469-90.

Nora, P., ed. 2002. Les Lieux de Mémoire, vol. I: La République. Paris: Gallimard.

Nyamnjoh, F. \& B. Page 2002. 'Whiteman Kontri and the enduring allure of modernity among Cameroonian youth', African Affairs IOI, 405: 607-34.

Olick, J. \& J. Robbins. I998. "Social memory studies: from "collective memory" to the historical sociology of mnemonic practices', Annual Review of Sociology 24: I05-40.

Passeron, J.-C. 1989, 'Biographies, flux, itinéraires, trajectoires', Revue Française de Sociologie 21 : 3-22.

Peel, J. I984. 'Making history: the past in the Ijesho present', Man (NS) I9, I: III-32.

Pels, P. 1992. 'Mumiani: the white vampire: a neo-diffusionist analysis of rumour', Etnofoor 5, I-2: I65-87.

Perrings, C. 1979. Black Mineworkers in Central Africa. London: Heinemann.

Petit, P., ed. 2003a. Ménages de Lubumbashi entre Précarité et Recomposition. Paris: L'Harmattan.

Petit, P. 2003b. "We are orphans, lost people, led astray by others": the aftermath of colonization in an African Kingdom (Luba-Haut-Katanga, Congo)', manuscript presented at the Amsterdam School for Social Science Research.

Ricoeur, P. 2004. Memory, History, Forgetting. Chicago, IL: University of Chicago Press.

Rubbers, B. 2006a. 'Congo Casino: le monde social du capitalisme européen au Haut-Katanga (RDC)', doctoral thesis, Brussels, Marseille. 
Rubbers, B. 2006b. 'L'effondrement de la Générale des Carrières et des Mines: chronique d'un processus de privatisation informelle', Cahiers d'Etudes Africaines I8I: II5-34.

Rubbers, B. 2007. 'Retour sur le secteur informel: l'économie du Katanga (Congo-Zaïre) face à la falsification de la loi', Sociologie du Travail 49, 3: 316-29.

Rubbers, B. 2008. 'Au temps béni de la colonie: le Congo belge dans la mémoire des anciens coloniaux et des anciens colonisés', in R. Giordano, ed. Autour de la Mémoire: la Belgique, le Congo et le passé colonial. Paris: L'Harmattan.

Stengers, J. I989. Congo: mythes et réalités. Ioo ans d'histoire. Louvain-La-Neuve: Duculot.

Stoler, A. L. 2002. Carnal Knowledge and Imperial Power: race and the intimate in colonial rule. Berkeley, CA: University of California Press.

Todorov, T. 1995. 'La mémoire devant l'histoire', Terrain 25: IOI-I2.

Turner, T. \& C. Young. 1985. The Rise and Decline of the Zairian State. Madison, WI: University of Wisconsin Press.

Vellut, J.-L. 1982. 'Matériaux pour une image du blanc dans la société coloniale du Congo belge', in J. Pirotte, ed. Stéréotypes nationaux et préjugés raciaux aux XIXième et XXième siècles: sources et méthodes pour une approche historique. Leuven: Editions Nauwelaerts.

Veyne, P. 1998 [1983]. Did the Greeks Believe in their Myths? An essay on the constitutive imagination. Chicago, IL: University of Chicago Press.

Vinck, H. 1999. 'Le mythe de Cham dans quelques livrets scolaires du Congo belge', Canadian fournal of African Studies 33, 2-3: 642-7.

White, L. 200o. Speaking with Vampires: rumor and history in colonial Africa. Berkeley, CA: University of California Press.

Young, C. 1965. Politics in the Congo: decolonization and independence. Princeton, NJ: Princeton University Press.

Zerubavel, E. 1996. 'Social memories: steps to a sociology of the past', Qualitative Sociology 19, 3: 283-300.

\section{Newspapers}

La Tribune, Lubumbashi.

\section{CAMBRIDGE JDURNALS}

